\title{
The Transformation of Women Objectification in Multimodal Literary Adaptation of Pride and Prejudice and Zombies: The Graphic Novel
}

\author{
Titien Diah Soelistyarini, Universitas Airlangga \\ Cindy Belinda Ramadhanty, Universitas Airlangga
}

\begin{abstract}
Traditionally, literary analyses have tended to concentrate on the analysis of narrative texts presented in words. However, many works of contemporary literature appeal to readers not only through texts, but also images and even audios. Graphic novel is a contemporary literary work that enables texts and images interact to create a complex whole. Adapted from a mash-up novel, Pride and Prejudice and Zombies: The Graphic Novel has shifted its mode of engagement from telling mode in narrative literature into showing mode in graphic adaptation. Focusing on women's portrayal in the graphic novel adaptation, this paper discusses how the interaction of texts and images affect women objectification in the story. Hence, by applying Kress' multimodality, Nussbaum's objectification, and Kukkonen's graphic novel theories, this paper reveals that the way visualand verbal modes complement each other tointensify the objectification depicted in the graphic novel.
\end{abstract}

Keywords: graphic novel; literary adaptation; mise-en-page; multimodality;women objectification

\section{Introduction}

Before graphic novel rose to prominence in the 1990s, literature mostly referred to narrative texts presented merely in words. However, since the publication of Will Eisner's A Contract with God (1978), not only words but also images began to appear in a new form of literature known as graphic novel. Kukkonen (2013: 85) states that the component novel in the term graphic novel connects comics explicitly to the larger category of literature. Employing different modes, namely visual, spatial and verbal, as parts of the narrative texts, graphic novel has broken traditional literary convention relying more on authors' word art and craft in conveying messages and delivering literary aesthetics.

By shifting its mode of engagement from telling mode in narrative literature into showing mode, graphic novel became a fitting medium to see how both verbal and visual modes work together to create meaning and representation in communication. Kress (2008: 91) refers to the use of these different modes for communication as multimodality. In addition, Hammond (2012: 23) asserts the importance of acquiring multimodal literacy. Accordingly, to acquire multimodal literacy using graphic novel, there have been various researches show how graphic novel is used in high school classrooms to understand more about the meaning of multimodality (Connors, 2012; Hammond, 2009, 2012; Beenfeldt, 2016), how multimodal analyses are found in graphic novel (Schwartz \& Rubinsten-Ávila, 2006; Gibbons 2014; Chu \& Coffey, 2015), and how to use graphic novel as an object to improve critical literacy for English-language learners (Carter, 2007; Serafini, 2012; Chun, 2009).

As graphic novel is becoming more and more interesting to study, this paperaims to reveal the way verbal and visual modes in Pride and Prejudice and Zombies: The Graphic Novel (2010) depict women objectification. The graphic novel was adapted by Eagle Award winner and writer, Tony Lee, from the first and renowned mash-up novel Pride and Prejudice and Zombies (2009) by the late English novelist, Jane Austen, and American screenwriter, Seth Grahame-Smith. The novel is considered as the trendsetter of mash-up novels since it has spurred similar publication mashingup classics with horror-action genre by adding contemporary and postmodern elements like 
zombies, vampires, werewolves, sea monsters, mummies, and androids to the original canonical literature (Chretien, 2011:8).

Pride and Prejudice and Zombies: The Graphic Novel provides an example of a contemporary literary work that portray women objectification.Nowadays, most women are able to show that they are equal in terms of rights and power to men. Yet, in reality women are still considered as inferior in comparison to men in a patriarchal society. There are still some cases in which women are seen as an object by the opposite sex. In feminist perspective, this phenomenon is called as objectification. The depiction of women objectification on the main female character in the graphic novel, thus, becomes the main focus of this study.

The concept of women objectification was developed by Martha Nussbaum (1995: 257) who argues that a person is objectified when they are seen and/or treated in one or more of seven features that are involved in the idea of treating a person as an object, namely: (1) Instrumentality: treating a person as a tool for the objectifier's purposes; (2) Denial of autonomy: treating a person as lacking in autonomy and self-determination; (3) Inertness: treating a person as lacking in agency, and perhaps also in activity; (4) Fungibility: treating a person as interchangeable with other objects; (5) Violability: treating a person as lacking in boundary-integrity; (6) Ownership: treating a person as something that is owned by another (can be bought or sold); and (7) Denial of subjectivity: treating a person as something whose experiences and feelings (if any) need not be taken into account.

Women objectificationis not a totally new issue in a literary research. There have been numerous studies discuss objectification in various literary texts, including objectification towards Pope's Rape of the Lock main protagonist, Belinda (Ferguson, 1992); How disability can play a big role in objectifying woman in James Joyce's Nausicaa (Bednarska, 2011); And masculine sexuality and women objectification in Steinbeck's perspective (Gladstein, 2004). All of these studies reveal various portrayals of women in literary works who are treated as object, as less than a person they are entitled for due to their inferior status in the predominantly patriarchal society.

However, these researches on women objectification in literature have so far only been examined through a single mode, namely the verbal mode. Thus, the lack of researchon women objectification in multimodal literary adaptation has prompted this study on Pride and Prejudice and Zombies: The Graphic Novel to examine how visual, spatial, and verbal modes of communication intensify or reduce the objectification in the graphic novel. As now we are all living in a visual age in which the graphic novel is becoming more prominence for providing the visualization of the characters from mere words in the novel into drawings in frames. As Kress and Van Leeuwen (2006:41) state that in today's age of multimedia, the multimodality of written texts start to regain recognition.

\section{Method}

As this study expected to reveal the transformation of women objectification in multimodal literary adaptation of Pride and Prejudice and Zombies: The Graphic Novel, a close reading was conducted to sort out the way female characters, particularly the main female character, Elizabeth Bennet, was treated as object as seen through both verbal and visual modes. Data for the verbal mode include dialogues and narrative aspects, such as characterization and plot, while data for the visual mode include non-narrative aspects, such as speech bubbles, facial expressions, and mise-enpage, as outlined by Kukkonen (2008). Meanwhile, out of seven, four of Nussbaum's features of objectification were used to analyze the transformation of women objectification in the graphic novel, namely instrumentality, fungibility, ownership, and denial of subjectivity. Analysis of the non-narrative aspects employed cognitive approach as referred to the process of making meaning through cues that were provided in the graphic novel. In addition, Kress' multimodality was applied to analyze the interaction of the different modes of communication in the graphic novel reveal the 
transformation of women objectification as reflection of the society pictured in the novel and the time it was published.

\section{Discussion}

As the main female character ofPride and Prejudice and Zombies: The Graphic Novel, Elizabeth Bennet (Lizzy)is seen as an object by Mr. Collins, Mr. Bennet's cousin. Mr. Collins is a 25-year-old clergyman whose father was not in a good relationship with Mr. Bennet. Given the fact that Mr. Bennet has five daughters instead of sons, Mr. Collins would be the one to inherit Longbourn once Mr. Bennet passed away as he is the closest male relative to Mr. Bennet.

One day, Mr. Bennet tells his wife and his five daughters that Mr. Collins is going to visit Longbourn(Austen, Grahame-Smith \& Lee,2010: 27). It turns out that his visit to Longbourn is actually intendedto find himself a suitable wife. As seen in Figure 1, panel 2 (panels are usually seen from the top left of the page to the bottom right), when Mr. Collins stated that he "came to Hertfordshire with the design of selecting a wife" (Austen, Grahame-Smith\& Lee 2010: 42). The word "wife" is written both in italic and bold, emphasizing Mr. Collins'strong intention to marry. His facial expression shows us that he (somehow) looks at Lizzy with such a condescending look, as seen in panel 4, when he tells her that "I will require you to retire your warrior skills as part of your marital submission" (ibid). The word "marital submission" is also written both in italic and bold, emphasizing Mr. Collins' demand to Lizzy if she were his wife. The way Mr. Collins is pictured in the mise-en-page of Figure 1 shows that he is the dominant character in the page, as his face is shown clearly from the front in panel 1,2, and 3; compared to Lizzy'sface that is shown only from her left side in panel 1, 2, and 4. This shows that Mr. Collins is the superior and Lizzy is the inferior one.

The way Mr. Collins treats Lizzy can be considered as instrumentality, the act of treating someone as a tool for the objectifier's purpose(Nussbaum, 1995: 257). In this case, Mr. Collins is the objectifier and Lizzy is the objectified since Mr. Collins is the one who objectifies Lizzy. Mr. Collins only needs Lizzy to be his potential wife-to-be because he wishes to fulfill his need of finding a wife. Moreover, Mr. Collins becomes the superior one because he holds the power over Lizzy, as young women in the Regency Era are expected to marry early. Betts (2015) states that in the Regency Era "a good marriage to a man with a comfortable income was vitally important for a woman as she rarely had another means of financial support." This place Lizzy as the inferior one because she ought to accept Mr. Collins' proposal no matter what, otherwise she would not find a husband that will take care of her after her father passed away.

Looking at those narrative and non-narrative aspects in Figure 1, we can assume that $\mathrm{Mr}$. Collins is objectifying Lizzy in a way that he only needs her as his potential wife-to-be as he needs to marry a woman. It does not really matter for Mr. Collins whether the other party loves him or not, because all he needs is a wife. Love is not a necessary part of the deal. In Figure 1, he does not take into consideration whether Lizzy likes him or not, instead he confidently makes a proposal as if Lizzy will accept him and do as he says - to the extent that she will quit being a warrior and become a full housewife instead. Mr. Collins here does treat Lizzy as a tool for his purpose, that is, to marry.

As the story goes by, it is revealed that Mr. Collins is objectifying another female character in a similar way to Lizzy. The female character is none other than Lizzy's best friend, Charlotte Lucas. Mr. Collins also proposes to Charlotte upon being rejected by Lizzy (Austen, GrahameSmith \& Lee,2010: 50). We can assume that Mr. Collins is objectifying both Lizzy and Charlotteas interchangeable, or also known as fungibility(Nussbaum, 1995: 257).Unable to marry Lizzy, Mr. Collins then moves on to Charlotte and tries to propose her hoping she will say yes and he will get himself a legal wife. 
Figure 1:Mr. Collins attempted to propose Elizabeth Bennet

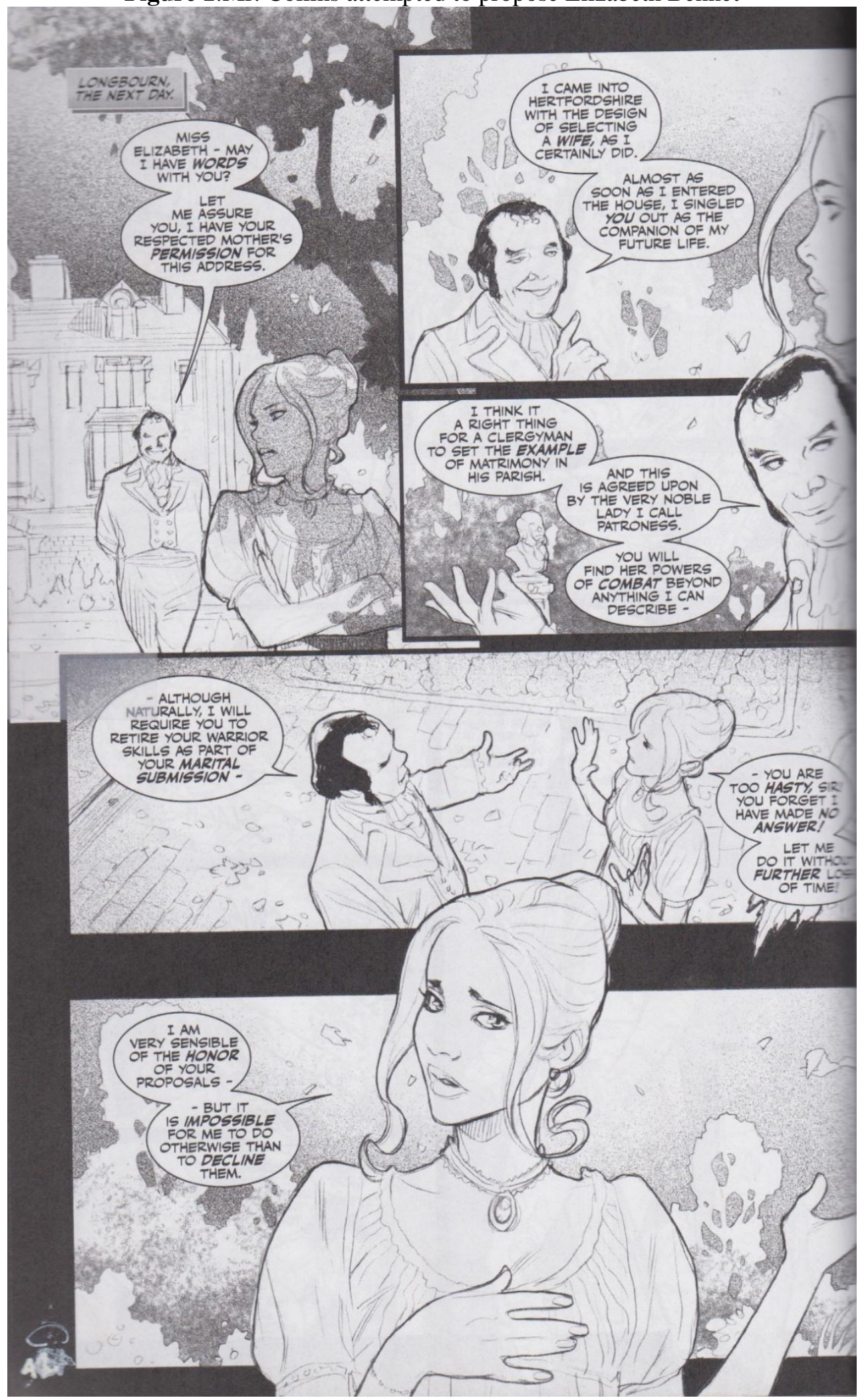


Thus, for Mr. Collins, his future wife does not have to be Lizzy, or Charlotte, in particular; as long as it is a woman suitable enough to marry, then she will do. Mr. Collinsbasically only needs a woman to be his wife, with no preference or love (romance) whatsoever towards his future wife. In other words, Lizzy experiences not onlyinstrumentality but alsofungibility as clearly seen in Figure 1.

Lizzyis also seen as something that can be traded by her own mother, Mrs. Bennet, and Mr. Collins. The act of treating someone as if he/she can be traded, bought or sold by other people is called as ownership (Nussbaum, 1995: 257).As seen in Figure 2, after Lizzy turns down Mr. Collins' proposal, Mrs. Bennet tells Mr. Collins, "Depend upon it, Mister Collins - Lizzy will be brought to reason. She is a very headstrong, foolish girl and does not know her own interest - but Iwillmake her know it" (Austen, Grahame-Smith \& Lee,2010: 43). The wordwill in both occurrences are written in italic and bold, emphasizing Mrs. Bennet's role in treating Lizzy as an object as it implies that she owns Lizzy and she can guarantee Mr. Collins that Lizzy will never turn down his proposal ever again. Mrs. Bennet speaks as if Lizzy is a product that can be bought or sold easily through a deal/agreement.

Mrs. Bennet here acts as the patriarchal agent, meaning that she has a role to get all her five daughters married to a proper man, with no exception to Lizzy. As stated by Mr. Bennet at the beginning of the book, "But remember - it's your job to get them married - but it's my job to keep my daughters alive"(Austen \& Grahame-Smith, 2010: 3). In panel 4, Mrs. Bennet is pictured standing behind Mr. Collins; her feature is blurred due to the focus is on Lizzy, actually, even though Lizzy's face and body only pictured in half (left side only). In the last panel, however, Mrs. Bennet is pictured clearly as well as Mr. Collins; they both are pictured in close-up, showing their facial expressions that show as if they are in an agreement. Mrs. Bennet looks at Mr. Collins while holding her parasol, meanwhile Mr. Collins looks at her convincingly. The way Mr. Collins looks at Mrs. Bennet implies that he is convinced that Mrs. Bennet can persuade Lizzy in accepting his proposal. It can be inferred that Mrs. Bennet here acts as 'the dealer' and Mr. Collins as the customer, as they both are treating Lizzy as if she is something that can be bought or sold.

Looking at both verbal and visual modes, we can assume that Mrs. Bennet is the superior one, since being Lizzy's mother. She holds the ultimate power over Lizzy. Her facial expression in the last panel shows that she is very confidence in persuading Lizzy to accept Mr. Collins' proposal. The way Mrs. Bennet gives a brief smile when Mr. Collins looks at her (somehow) implies that Lizzy is the inferior one as she (implicitly) has to obey Mrs. Bennet's command in accepting Mr. Collins's proposal. Mrs. Bennet is optimistic that once she gives Lizzy some of her pieces of mind, Lizzy will accept Mr. Collins's proposal. It can be seen implicitly that Mrs. Bennet has an authority over Lizzy which acts as her advantage in convincing Mr. Collins that Lizzy will accept his proposal. In this case, Mrs. Bennet is the objectifier, while Lizzy is the objectified, as Mrs. Bennet no longer sees Lizzy as her daughter, a human being, but rather as something that can be traded, bought or sold to someone else; which in this case, Lizzy is 'traded' to Mr. Collins.

Not only does Lizzy experience ownership, she alsoexperiences what Nussbaum (1995: 257) calls as denial of subjectivity. As seen in Figure 2 panel 2, 3, and 4, when Lizzy tells Mr. Collins as follows:

Elizabeth: You forget, Sir, that I am a student of Shaolin! Master of the seven-starred fist! I am perfectly serious in my refusal. You could not make $\boldsymbol{m e}$ happy - and I am convinced that I am the last woman in the world who could make you so! I am a warrior, Sir - and shall be until my last breath is offered to God. Really, MisterCollins - you puzzle me exceedingly! I know not how to express my refusal in such a way as to convince you of its being one!(Austen, Grahame-Smith \& Lee 2010: 43). 
Figure 2:Elizabeth Bennet turned down Mr. Collins’ proposal

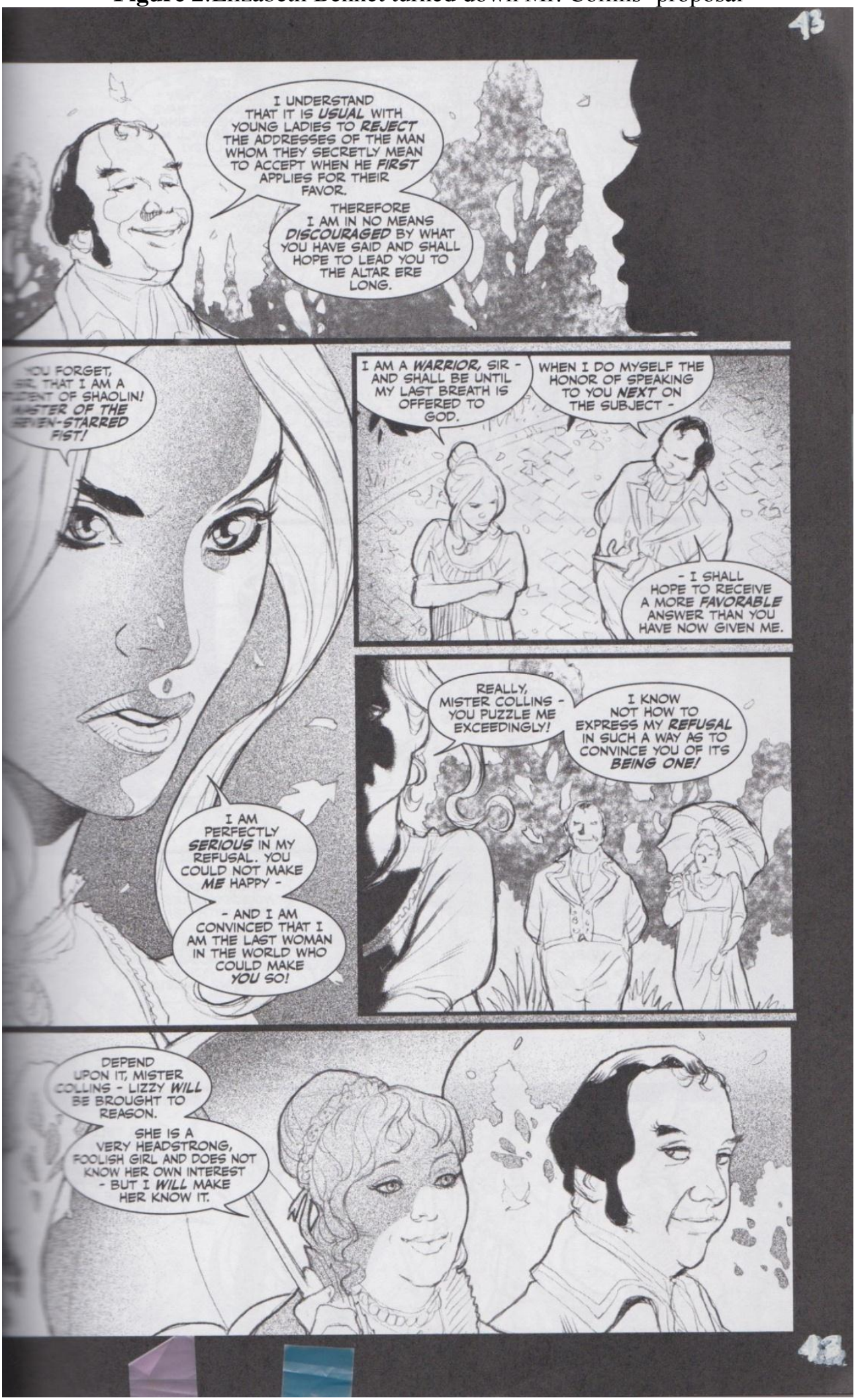


The words written in bold and italic both emphasize Lizzy's strong reasoning as to why she refuses Mr. Collins' proposal. Her facial expression in panel 2 really shows her determination in refusing Mr. Collin's proposal; she is pictured raising both her eyebrows. Panel 2 also becomes the background for panel 1, 3, 4, and 5 (the foreground), meaning that panel 2 actually serves as the base of the mise-en-page of Figure 2. This shows that Lizzy is the dominant character of Figure 2, with the exception of the last panel, as she always appears in each of the panels. Meanwhile, in panel 3, Lizzy is pictured folding both her hands in front of her, implying that she will not change her opinion in refusing Mr. Collin's proposal. In the next panel, Lizzy is shown leaving the place, as she thinks that there is no better explanation for Mr. Collins other than telling him directly that she strongly refuses his proposal. Lizzy is pictured rather from her left side though, with only her left eye that can be seen from afar, but still indicating that she will not change her mind.

Despite her efforts in refusing Mr. Collins's proposal, Lizzy's feelings and opinions about the matter are not taken into account by her mother, Mrs. Bennet. As seen in Figure 2, after Lizzy turns down Mr. Collins's proposal, Mrs. Bennet tells Mr. Collins, "Depend upon it, Mister Collins Lizzy will be brought to reason. She is a very headstrong, foolish girl and does not know her own interest - but Iwillmake her know it" (Austen, Grahame-Smith \& Lee 2010: 43). The word will in both occurrences are written in italic and bold, emphasizing Mrs. Bennet's role in treating Lizzy as an object as it implies that she does not take into account Lizzy's feelings and opinions regarding the matter.

\section{Conclusion}

This paper has explored the implications of using a multimodal graphic novel, Pride and Prejudice and Zombies: The Graphic Novel, to present a narrative featuring Elizabeth Bennet, a woman of Regency Era who experiences objectification. Analysis of this graphic novel showed thatimages and words interact to enable readers to see how Lizzy as the main female character experiences objectification. As each writing and imagehas its distinct potentials for meaning,in this black and white graphic novel, both the writing and the images carry significant meanings as they complement each other in depicting the objectification. In fact, the working together of these multi modes in portraying the objectification towards Lizzy revealed that the facial expressions and miseen-page (visual mode) helped intensify the objectification presented through the dialogues between the characters (verbal mode).

\section{References}

Austen, J., Grahame-Smith, S., \& Lee, T. 2010. Pride and Prejudice and Zombies: The Graphic Novel. New York: Del Rey.

Beenfeldt, C. E. 2016. The Graphic Novel: Multimodal Reading in the Norwegian Upper Secondary EFL Classroom: A Case Study. Retrieved from University of Bergen Open Research Archive (BORA). Available athttp://hdl.handle.net/1956/12346.

Bednarska, D.2011.A Cripped Erotic: Gender and Disability in James Joyce's "Nausicaa".James Joyce Quarterly, 49 (1): 73-89. Available at http://www.jstor.org/stable/24598694. (Accessed 8 June 2017).

Carter, J. B. 2007.Transforming English with Graphic Novels: Moving toward Our "Optimus Prime". The English Journal, 97(2), 49-53.

Chretien, E. 2011. Gentility and the Canon Under Siege: Pride and Prejudice and Zombies, Violence, and Contemporary Adaptations of Jane Austen. Dissertations, Theses, and Student Research. University of Nebraska.

Chu, K. \& Coffey, S. 2015. Multimodal Analysis of Graphic Novels: A Case Study Featuring Two Asian Women Travelers. Intercultural Communication Studies, 24(1), 145-166. 
Chun, C. W. 2009. Critical Literacies and Graphic Novels for English-Language Learners: Teaching Maus. Journal of Adolescent \& Adult Literacy, 53(2), 144-153.

Connors, S. P. 2013. Weaving Multimodal Meaning in a Graphic Novel Reading Group. Visual Communication, 12(1), 27-53.

Ferguson, R.1992. 'Quick as her Eyes, and as unfix'd as those': objectification and seeing in Pope's "Rape of the Lock".Critical Survey, 4 (2): 140-146. Available at http://www.jstor.org/stable/41555644.(Accessed 8 June 2017).

Gibbons, A. 2014.Multimodality in Literature: An analysis of Jonathan Safran Foer's 'A Primer for the Punctuation of Heart Disease'. In S. Norris and C. D. Maier(eds.),Texts, Images, and Interactions: A Reader in Multimodality, Berlin/New York: Mouton De Gruyter, 371-380.

Gladstein, M. R.2004. Masculine Sexuality and the Objectification of Women: Steinbeck's Perspective. The Steinbeck Review, 1 (1): 109-123. Available at http://www.jstor.org/stable/41581952.(Accessed 8 June 2017).

Hammond, H. K. 2009. Graphic Novels and Multimodal Literacy: A Reader Response Study. Retrieved from the University of Minnesota Digital Conservancy.Available at http://hdl.handle.net/11299/48560. . 2012. Graphic Novels and Multimodal Literacy: A High School Study with American Born Chinese. Bookbird: A Journal of International Children's Literature, 50(4), 22-32.

Kress, G. 2003. Literacy in the New Media Age. New York: Routledge. . 2008. "Literacy" in a Multimodal Environment of Communication. In J. Flood, S. B. Heath and D. Lapp (eds.), Handbook of Research on Teaching Literacy through the Communicative and Visual Arts, Volume II, New York/London: Lawrence Erlbaum, 91100.

Kress, G. \& Van Leeuwen, T. 2006. Reading Images: The Grammar of Visual Design. New York: Routledge.

Kukkonen, K. 2013. Studying Comics and Graphic Novels. New Jersey: Wiley-Blackwell.

Nussbaum, M. 1995. Objectification. Philosophy and Public Affairs, 24(4), 249-291.

Schwartz, A. \& Rubinsten-Ávila, E. 2006. Understanding the Manga Hype: Uncovering the Multimodality of Comic-Book Literacies. Journal of Adolescent \& Adult Literacy, 50(1),40-49.

Serafini, F. 2012. Reading Multimodal Texts in the $21^{\text {st }}$ Century. Research in the Schools, 19(1), 26-32. 